\title{
The geontological time-spaces of late modern war
}

What if our analyses of war begin in the ground? What if the point of entry into critique is not the targeting technologies of warfare but the earth and bodies that are targeted? Viewed from the ground through which toxins seep and the bodies whose cells mutate, how are we brought to understand power and the temporal and spatial dimensions of war? And what, therefore, are the ensuing empirical and theoretical lessons for geography? It is from these questions that the discussion here begins, attending to time, space and power as they are revealed through the soils and aquifers that sustain life in areas affected by contemporary or "late modern" practices of war. In these areas, the remnants of "precision" munitions persist in the gradual and pronounced harm caused to ecological systems and public health that contour the notion of "late modern war" in particular ways. Temporally, harm is not confined to the immediacy of military strikes but emerges via processes - leaching toxins, cellular dysfunction, radioactive decay, genetic mutations - over months, years, generations. Spatially, the "remote" provenance of violence from Nevada's "drone vans" is a footnote to the issue of proximity to war's ecological fallout, and the significance of verticality consists less in the proliferation of aerial technologies above than the threat they pose via residues in the ground below. Approached this way, the violence of late modern war is at once subterranean, hydrological, agricultural, molecular, cellular, genetic, teratogenic, carcinogenic, and thus - crucially - effected via a dissolution of boundaries between "life" and "nonlife".

The objective of this article is to expand on these initial observations to develop a geographical agenda for examining power in late modern war from the perspective of the ground and the life it sustains. The rationale for such an inquiry is drawn from urgent and (to date) fragmentary evidence from parts of Iraq (Fallujah, Basra), Afghanistan (Kabul, Kandahar) and Gaza where doctors have documented significant increases in serious health conditions such as congenital disorders and cancers, noting also patient proximity to munitions residues (e.g.: Alaani et al., 2020; Manduca et al., 2017; Naim et al., 2012). In each of these contexts, advanced militaries (US, UK, Israeli, coalitional forces) have deployed technologies orientated around a set of cognate logics where warfare is "precise", "scrupulous", "surgical" and so on. The response from geographers and other social scientists has been to develop a thoroughgoing critique of these logics, deconstructing military claims of more "ethical" operations and drawing focus on the ways that war - and the power of war - issues from its increasingly compressed and aerial time-spaces (e.g., Gregory, 2011b; Jabri, 2006; Jones, 2020; Joronen, 2016; Zehfuss, 2011). Notable also within this work is that the time-space of critique is rendered commensurate with a specific time-space of war: violence is enacted via remote systems from above with immediate results; critical examination apprehends time and space as such, and knowledge is shaped in this image. A large part of our understandings of late modern forms of war are thus angled towards the intentions and/or practices of militaries rather than towards those (and that) affected. Put more 
strongly: existing perspectives can be bound by a militaristic ontology that obscures from view a large portion of harm wrought by military activities. This sense forms the basis of the discussion here in which war's residues in the ground are positioned as central to the function of power in late modern war.

A thread that runs through existing studies into ongoing threats to health in places such as Fallujah, Kandahar and Gaza City is a contingency between i) war's materiality, specifically the residues of harmful munitions; ii) the Earth's constitutive elements, soil, water, air; and iii) the body's vulnerability to ecological change. In the temporal and spatial re-ordering of war, a mode of power works through and between nonlife and life: militarism rouses the environment towards its destructive ends, depositing "lifeless" byproducts that animate the landscape to extract its ultimate commodity, the ruination of targeted life. To hand in this respect is not so much a bio-/thanato-political mode of power that designates and denigrates life, but one that operates over and via a foundational distinction between life and nonlife, or what Elizabeth Povinelli (2016) has termed 'geo-ontopower' (also: Massumi, 2015: 40). For Povinelli (2016: 5), the geos is a missing piece in the analysis of power that reveals a conceit common to the ontologies of late liberalism whereby bios and zoe are the metaphysical measures of being-that-is-valued - and thus the grounds of politics. These 'covert biontologies', Povinelli (2016: 173-174) shows us, obscure from view not only the geo-ontopower that marks the ontological division between life and nonlife but also that which animates the latter to the ends of instrumentalising the former via 'a set of dominant patterns ... according to which Life is fabricated and Nonlife is used'. A part of this analytic provides a grammar of geos as an alternatively inanimate and animating domain that serves to further our understandings of the ways that the ground is vital to the violence of war. The main conceptual contribution of this article is to explicate this as a key and geontological mode of power in late modern forms of war

The article proceeds in four main sections. The first presents a necessarily abridged summary of existing research on long-term health in affected areas of Iraq, Afghanistan, and Gaza. The abridgement is owed to constraints of space here but also to limits on conducting research, both infrastructural and in terms of research agenda. Beginning a response to these limits, the second section surveys scholarship on contemporary practices of war and makes the case that current formulations of time, space, and subjects (e.g., "civilian", "non-combatant", "collateral damage") tend to foreclose the residues of war in the ground that threaten life. A case thus builds that beginning with the ground requires a significant re-dimensioning of time-space in our empirical and theoretical approaches to late modern war. Towards an empirical agenda, section three returns to Iraq, Afghanistan, and Gaza to develop an aetiology of the harms that emerge through the contingencies of life and nonlife. The fourth section works on a more theoretical plane to consider the function of power in these contingencies as geontological, or that which hinges on designating and animating nonlife for deadly ends. The article concludes with reflection on how geographers - in both "physical" and "human" sub-fields - are uniquely equipped to inform and lead research on the geontological time-spaces of late modern war. 


\section{THE RATIONALE (ABRIDGED): WAR AND PUBLIC HEALTH IN IRAQ, AFGHANISTAN, AND GAZA}

The purpose of this short section is to anchor the discussion in the long-term health effects of advanced military activities by surveying existing research from Iraq, Afghanistan and Gaza.

Owing to the longevity of military operations and a relatively resilient university infrastructure, by far the most research in this area has been conducted in Iraq. Examination of a 17 -fold increase in congenital disorders in the cities of Fallujah and Basra, for instance, identifies exposure to weapons residues and higher-than-normal (5-6 times) levels of toxic metals (mercury, lead, uranium) in the environment as a probable cause (al-Sabbak, 2012). In Fallujah specifically, a team of medics has concluded that 'the metal load of Falluijes in general is unusually high for metals associated with weaponry' and that this 'can condition differently MS [miscarriage] and BD [birth defects]' (Alaani et al., 2020: 8; Alaani et al., 2011; 2012; alSabbak, 2012). Research by oncologists in Basra has attributed higher-than-normal levels of uranium in blood samples of leukaemia patients to the fact that 'Basrah is the region which received the highest amount of DU [depleted uranium] during the Gulf Wars' (Al-Hamzawi et al., 2014: 1271). In the northern city of Mosul, researchers have examined how depleted uranium deposits carve new 'pollution pathways' that 'may have serious impacts on the regions' food chains and subsequently on human health across Iraq: largely through plant uptake and edible food crops' (Fathi et al., 2013: 7). A further study in Iraq presents correlating evidence of residential proximity to harmful weapons (both stored and discarded) around a USoperated air base and the presence of contaminants in biological samples: 'children who live [nearby] have up to 28 times more thorium in their deciduous teeth than children who lived farther away' (Savabieasfahani et al., 2020: 7). The concern in this case - and one that applies each of these studies from across Iraq - is that 'epidemiological evidence is consistent with an increased risk of congenital abnormalities in the offspring of persons exposed to uranium and its depleted forms' (Savabieasfahani et al., 2020: 6).

Researcher access and facilities in Afghanistan are severely limited. It is, however, crucial to keep it in view for the prospect of similar and - given the two decades-long US-led operations there - potentially profound effects on Afghanistan's environment and population. There are indications in this direction: a 2008 BBC report drew attention to a doctor [anonymous] in Kabul who documented 'premature births and malformations' including 'neural tube defects and malformation of limbs; for example, the head is smaller than normal, or the head is larger than normal, or there is a big mass on the back of the baby'. The report adds that 'villagers near the Tora Bora mountains' - that were subject to massive bombardment in 2001 'suspect the bombs brought an increase in diseases and other problems' and recount that a number of babies born soon after have malformed limbs and facial features (BBC, 2008). The work of the late Bosnian doctor Asaf Duraković (2005) and the US-based charity he founded, the Uranium Medical Research Center, is also relevant for its recording of significantly elevated levels of uranium isotopes in urine samples in areas of contaminated soil and water supplies in eastern Afghanistan.

A larger amount of research has been conducted in Gaza where there are pronounced concerns around the territory's environmental fragility. A large-scale investigation published by the Palestinian Environmental NGOs Network (PENGON, 2015: 19; 32) criticises Israel's 'massive use of unconventional 
weapons' in 2014 ("Operation Protective Edge") that left residues to 'percolate slowly into the aquifer, adding pollutants such as cadmium, copper and lead [that] pose serious health risks including cancer'. One such 'unconventional' weapon, white phosphorus, whose constitutive chemical is prevalent in high concentrations in the northern part of Gaza, has given cause for scientists to warn it could 'destroy the natural ecosystem of animals and plants and contaminate agricultural products through the food chain ... caus[ing] health problems especially among children and the elderly' (Hamada et al., 2011: 297; Manduca et al., 2009). According to epidemiological research at Al-Shifa Hospital in Gaza City, this process is already in train where doctors have found a 'strong correlation of BD [birth defect] newborns and parent's exposure to attacks with WP [white phosphorus]' (Naim et al., 2012: 1744-45). Study into other 'unconventional' weapons such as so-called 'weapons without fragments' - i.e., DIME (Dense Inert Metal Explosive), or "tungsten bomb" - demonstrates the presence of toxic and carcinogenic metals in the fragment-free wounds they produce that, doctors advise, 'carries unknown long-term risks for survivors' (Skaik et al., 2010: 1). Connectedly, a large-scale study into the health of hundreds of women from Gaza who were pregnant during the 2014 bombardment found significantly high levels of heavy metals - tungsten included - in both mothers and their new-borns that doctors interpret as evidence that 'the risks posed by the war remnants are diffuse, may not be limited to reproductive health and may also affect the frequency of pathologies such as cancers, male sterility, immunity and endocrine disorders' (Manduca et al., 2017: 19).

Each of the studies cited here stresses the need for further work, especially because many of the effects are unknown and/or yet-to-come, a fact that is exacerbated by the secrecy around weapons manufacture that presents a barrier for clinical practice. The account here is thus abridged not only for reasons of space but also for a paucity of work due to lack of resources and the "classified" status of crucial information such as the material make-up of munitions (this important point is returned to below). Taken cumulatively, however, the studies surveyed here indicate that contemporary military practices effect harm via a residual materiality (phosphorus, uranium, tungsten) in the environment that diminishes the life it sustains.

\section{LATE MODERN WAR: TIME, SPACE, SUBJECTS}

The practices of warfare that have deposited these threats to life are usefully described by Derek Gregory (2010: 160) as definitive of "late modern war", a technology-driven way of war enabled by 'advanced systems of sensing and surveillance from air and space platforms .... and weapons systems revolving around pilotless aircraft, robotic vehicles and precision-guided weapons'. In this section I consider how scholars examine these advanced systems of war along three prominent themes - time, space and subjects - to sketch out the ontological bounds of existing knowledge that can thus inform further research.

Where time is an organising principle of inquiry, pre-emption, compression and efficiency are each brought to the fore. Pre-emption is now a routine logic of specific military activities (e.g., targeting) and wider strategies of intervention that seek to identify 'people and threats before their deadly potential is realised' (Graham, 2010: xii). In this sense, "late modern" denotes an epochal shift from a Cold War logic of 
deterrence to one of anticipation and eradication of the (often exaggerated) potentials of groups and states designated "terrorist" and/or "rogue". It is around this anticipatory figuring of time - a form of what Brian Massumi (2015) terms "ontopower" - that domestic security and overseas intervention are re-organised to counter threats to "the homeland" (Aradau and Van Munster, 2012). Compression comes into view with a focus on the operational details of this logic where "real-time" intelligence reduces the time between identifying and killing a target to 'hours and minutes, rather than days, weeks, or months' (Jones, 2020: 24). This dynamism is at the core of multiple other practices, from 'personality strikes' of known persons and 'signature strikes' based on 'pattern of life' data (Wilcox, 2015) to the use of terrain-specific munitions such as 'bunker bombs' in mountainous regions (Bell, 2008) and 'roof knocking' light explosives in urban settings (Joronen, 2016). In each their own way, these tactical and technical developments quicken the pace of doing war, obliterating lives 'in an instant' (Benjamin, 2013: 28). Pre-emption and compression can thus be seen as hyponymic to an overarching military ideal of efficiency whereby interventions are figured as "quick-fix" or "surgical" (Shaw, 2005: 76-77), and thus not only efficient but finite acts of war.

On the question of space, verticality and remoteness are prominent themes of critique. The vast part of literatures focused on the 'vertical field' of late modern war draws focus on the aerial assemblages comprising drones (Agius, 2017) and GPS/GIS technologies (Beck, 2003; Kaplan, 2006; Zehfuss, 2011) that provide intelligence and deliver "smart" munitions to enemy targets below. Taking this vantage point on contemporary military practice allows a clearer view on how, for instance, Israel maintains its 'airborne occupation' of Palestine via GPS and radio hardware that form a 'single synergetic reconnaissance and killing instrument' (Weizman, 2007: 212) or the ways that US drone surveillance technologies (re)racialise targets in Pakistan, Somalia and Yemen via infrared imagery that reduces bodies to suspects according to the energy they emit (Parks 2017, 145). A second focus within literatures of verticality falls on the geological layers below the Earth's surface. Looking downwards reveals how aerially dominated populations, such as that of besieged Gaza, have turned to tunnels for vital supplies of fuel and medicines (Elden, 2013) and/or to appropriate 'geophysical agency' in practices of resistance (Slesinger, 2020). Underground tunnel space is thus simultaneously shelter and target; an infrastructure of survival but also a "justification" for bombardment and intensified surveillance (Bishop, 2011). The same can be said for the network of caves and tunnels in eastern Afghanistan that Osama bin Laden made base, and that hastened the (re)development of weapons such as the Robust Nuclear Earth Penetrator ("bunker bomb) in the build-up to US-led coalition's heavy assault on Tora Bora in late 2001 (Bell, 2008).

Remoteness is most starkly illustrated at Creech Air Force Base in Nevada from where US drone missions are piloted: "inside that trailer is Iraq, inside the other, Afghanistan", as one Lieutenant Colonel told the journalist Robert Kaplan (2006: 81; Gregory, 2011a: 192; Müller, 2020: 8). Inquiry into remoteness centres on the tension between, on the one hand, how remotely piloted missions enable a 'parenthetical suspension of the 'real" that works 'to generate a type of causal disconnect, and consequent disavowal [of pilots'] relation to the killing that transpires on the ground in 'remote' Afghanistan, Pakistan or Yemen', as Joseph Pugliese (2016: 501) has argued. Remoteness in this sense reduces war to the banality of simulation 
(Baudrillard, 1995), a mode of killing based on "Play Station" functionality (Benjamin, 2013: 86-90) with the disturbing corollary of elevating pilots to a God-like omnipotence (Chamayou, 2014: 37-39; cf. Williams, 2011). On the other hand, there is a certain hi-res intimacy to drone piloting via which Euclidean remoteness gives way to topological relations between belligerent and target that are, nevertheless, mediated through a one-sided, and Othering 'scopic regime' (Gregory, 2011a).

The issue of subjects and war has long orientated around the distinction between combatant and non-combatant, and a blurring of the two is considered a 'quintessential characteristic' of late modern forms of war (Kinsella, 2011: 3). Albeit with colonial antecedents (Rockel, 2009), a range of subject positions take on new resonance in this period, from 'unlawful combatants' (Najjar, 2017: 64) and 'collateral damage' (Rockel and Halpern, 2009) to 'human shields' (Gordon and Perugini, 2020) and the contested designation of 'innocent civilians' (Kinsella, 2011: 1-23). The important concern among scholars examining these subject positions is their political manipulation - i.e., how civilians are "transformed into "quasi-combatants" (Gordon and Perugini, 2016: 183) - so that, ultimately, anyone is either target or "necessary" collateral. On a metaphysical level, scholars have connected these designations to biopolitics (Foucault, 1978; 2003) - and its deathly/colonial offshoots (Agamben, 1995; 2005; Mbembe, 2019) - to extrapolate the logics of military power that reduces life to(wards) its 'bare-ness'. This is important because it allows us to see how those under the technologised skies of late modern war are brought within a thanatopolitical order as homines sacri (e.g., Gregory, 2004: 62-63), or alternatively at various removes from bare life, for instance as responsible for their own survival (and thus also death) (Joronen, 2016) or as "maimable" and therefore not human enough for even for death (Puar, 2017: 140-141). Where the question of who is posed more empirically, the subjects of late modern war tend to be the "doers" of war - e.g., the drone operators who undertake the 'labour of killing' (Asaro, 2017: 283; Bryant, 2017; Gregory, 2011a) and returning veterans suffering postwar sicknesses (e.g., Nixon, 2011: 204-208) - or those caught within its humanitarian aftermaths and in need of refuge and rehabilitation (e.g., Dewachi, 2017; Loyd et al., 2018; Pascucci, 2017).

The point here is not to re-cover the vast literature on these themes but to distil the prevailing ways in which scholars build understandings of late modern war in terms of time, space and subjects. By way of brief critical summary, I want to engage with this existing scholarship in a fashion suggested by Michel Foucault (1997: 118-119): 'it is a question of a movement of critical analysis in which one tries to see how the different solutions to a problem have been constructed; but also how these different solutions result from a specific form of problematisation'. I read this as an interrogation of the limits of knowledge and an imperative to attend to the relations between critique and its object, especially to a movement where one shapes the other. To this end, it is significant that cases of, for example, increased birth defects and contaminated farmlands are set at the temporal and spatial margins of current inquiry. As a 'specific form of problematisation' - i.e., that of 'advanced systems of sensing and surveillance $\ldots$ pilotless aircraft, robotic vehicles and precisions-guided weapons' and so forth (Gregory 2010: 160) - there is thus a certain level of accord between critique and its object in that they cohabit, even if antagonistically, time-spaces that mutually 
cohere. Many existing critiques are thus angled towards the doing of war and more muted on its delayed and diffuse effects.

Substance to this claim consists in the aggregated conceptualisations of time, space and subjects in the work reviewed here. Time is taken as the (ethics of) speeding up war, thus remaining within the temporal limits set by the promise of "precision". This is not to argue that there is no recognition of the "network effects' of precision weapons (Gregory, 2006: 100) or a 'bomb now, die later' (Graham, 2010: 265) dynamic, but rather to point out a parallel between the deferred effects of war and a deferred agenda for research in which the "later" is seldom more than 'briefly mentioned' (e.g., Belcher, 2011: 6). Rob Nixon's (2011: 213) work (to which I return below) is an important outlier (also: Logan, 2018; Pugliese, 2020) in this respect for a focus on 'ecological and genetic time' but that it has become so prominent tells us of its distinction in two senses: its excellence is matched by its innovation, or a newness that betrays the ways that the 'ecologies of the aftermath' are disciplinarily peripheral. Space is similarly formulated: just as military practices look down on (and up from, Williams, 2013) the Earth, so too does most scholarly critique. Aerial standpoints afford very few "close-ups" of the ground (Kaplan, 2018: 185) and thus adopting a commensurate (and technocentric) view risks, as some critics have cautioned (Harker, 2014: 321), 'expunging' lives at ground level (also: Fluri, 2009; 2011). I would argue further that space is rendered in an anthropocentric and Eurocentric way: where the vertical axis extends downwards, the subterranean comprises not soils and water but tunnels and bunkers; and an analytics of remoteness privileges the provenance of violence over its effects in the "global borderlands", where war is anything but remote. On subjects, categories are bound temporally: non/quasi-combatant depends on the ongoing presence of a belligerent other; "collateral" is designated by a military administration; and "civilian" responds to the contested question of who is target-able under international law. In all cases, at the "conclusion" of war - or when a military declares a conclusion - these subject positions (with a telling exception: "veterans") dissipate, revealing them to be tethered to a militaristic ontology and leaving the problem of how to address lives lived in the context of war's enduring effects.

Current understandings of contemporary or "late modern" war are in this way rooted in the intentions and practices of militaries, almost entirely foreclosing the important trajectories of violence that form through different temporal and spatial dimensions, those that consist in war's harm to the ground and the life it sustains. Towards building an understanding of power and war equipped to attend to such timespaces, in the following section I take the symptoms of war documented above (Section 1) as diagnostics to develop an aetiology that can shape an empirical agenda for geographical research into late modern war.

\section{AN AETIOLOGY}

The case for aetiological thinking here is compelling for the fact that current information is fragmentary in a highly politicised area of knowledge production where research is subject to partisan scrutiny. A case in point is Samira Alaani and colleagues' $(2011 ; 2012)$ studies of congenital disorders in Iraq whose findings were countered in a WHO-backed Iraqi Ministry of Health report (The Nation, 2020) which was in turn questioned by physicians writing in The Lancet (Webster, 2013) and labelled a "cover up" by journalists and 
legal practitioners (Ahmed, 2013; Shah, 2014; see also: Logan, 2018: 271). This exchange is indicative of not only contested truth claims but also of a domain of knowledge whose power issues from absented information. As Skaik et al. (2010: 1) stress, in the treatment of war's wounded, it is the 'undisclosed nature of materials used in weapons' manufacture that presents 'difficulties with clinical management' and thus exacerbates 'unknown long-term risks' (emphasis added; see also: Hezlein-Lossius et al., 2020). That is, the absented information - or 'anti-transparency stance' on the toxicity of munitions (Logan, 2018: 257) - built into a military-dominated knowledge economy impedes health provision (Zwijnenburg, 2013; Zwijnenburg and Weir, 2016). This is a struggle over knowledge that takes shape along distinctly colonial and racial lines where careful work carried out by colleagues in (and often from) Mosul, Fallujah and Gaza City is discredited or ignored by experts in Geneva, Vienna and Washington who (at most) acknowledge only a 'negligible' threat posed by munitions deposits (e.g., Bleise et al., 2003).

These points are not raised in persuasive effort towards one or another perspective (that argument is already made by those conducting research) but rather to stoke circumspection around war's materialities whose composition and full health effects are obfuscated. A key question, as Rob Nixon (2011: 220) has put it, centres on how a precision strike 'doubles as a chaotic weapon [that] strikes down civilians who ... just happen to live down-wind in time'. While some munitions (e.g., Agent Orange) were indiscriminate and ecological by design, this is not the case for the precision munitions named in connection to health problems documented in Iraq, Afghanistan and Gaza. Depleted Uranium (DU), for instance, is an armourpenetrating material whose shells burn on impact, releasing uranium oxide that is chemically toxic and has a radioactive half-life of 4.51 billion years. A UN Sub-Commission on Human Rights (UN, 2003) has labelled DU a 'weapon of indiscriminate effect' and it is the subject of a vast and contested literature produced by a range of institutions (e.g., EPA, 2006; RAND, 2005; Royal Society, 2002; WHO, 2001) and from differing scholarly perspectives (e.g., Bleise et al., 2003; Fairlie, 2009). No definitive conclusion on the level of risk posed by DU can be reached by reading this extensive body of work ${ }^{i}$ but the range is telling: at best, the long-term effects are unknown; at worst, it carries both a chemical and radiological threat to life. There is evidence that DU leaches through soils into groundwater (Fahey, 2003: 3), that contamination levels could rise over time and pass into food chains (WHO, 2001: vi) and that its chemical carcinogenesis is 'without threshold', meaning that no matter how low the concentration, a risk of cancer remains (Fairlie, 2009: 52). Marc Herold (2009: 306-306) warns that the DU aerosol produced on impact contains particles measuring $0.5-5 \mu \mathrm{m}$ that are each, once ingested or inhaled, 'equivalent to having one chest X-ray per hour for life ... [and thus] ... the victim is gradually irradiated'.

White phosphorus (WP) is another material whose toxicity is also identified as a threat to life. WP is deployed in two ways: to aid precision by providing visibility, and as the smoke-producing component of mortars, artillery shells and grenades. Its incendiary properties have brought WP a large amount of attention from human rights groups (Amnesty, 2016; HRW, 2009a; 2009b) and doctors (Al Barqouni et al., 2010; Gilbert and Fosse, 2009) for the severe burns inflicted on people in (especially) Gaza and Iraq. The longerterm effects of WP residues, however, are less well understood but evidence can be pieced together to 
shape future inquiry. Both Public Health England (PHE, 2017) and the United States Environmental Protection Agency (EPA, 2000) recognise that chronic exposure to WP can result in necrosis of the jaw or "phossy jaw" - in which the jawbone and nasal cavities eventually breakdown. The Agency for Toxic Substances and Disease Registry (part of the US Department for Health) associates WP ingestion with 'liver, heart, or kidney damage, vomiting, stomach cramps, drowsiness, or death' and concedes that 'we do not know whether or not white phosphorus can affect the ability to have children or cause birth defects in people' (ATSDR, 1997: 2). These US and UK government agency assessments for "domestic" risk are useful for the light they shed on military activities that have left high concentrations of WP in the soils of parts of Gaza (Hamada et al., 2011; Manduca et al., 2009) and Iraq (Mojabi et al., 2010) that must therefore pose the very same risks to the health of people living there.

DIME (Dense Inert Metal Explosive) - also: "tungsten bomb" or "Small Diameter Bomb" - is another munition deserved of critical attention. Developed in the US specifically for "low collateral" urban targeting, DIME bombs disperse high-energy "micro-shrapnel" made up of tungsten alloys in an intense but small blast radius that makes the 'the lethal footprint [a] precision footprint' (GlobalSecurity.org, 2006). The deployment of the bombs is secretive, but it is widely reported that IDF jets dropped DIME during its 2006 and 2008-9 assaults on Gaza (JoPS, 2009; Al-Haq, 2014), causing instant effects such as dissolved limbs that confounded medical specialists and were the subject of high-profile calls for further research in the British Medical Journal (Dyer, 2009) and The Lancet (Wolf et al., 2009). Of subsequent concern has been the indication that the effects of DIME might be just as devastating in the long-term: it ignites through a process of fission, making residues potentially radioactive (DemocracyNow, 2009); exposure to weaponsgrade tungsten is connected to lung metastases, polycythaemia, and a form of muscular cancer called rhabdomyosarcoma (Kalinich et al., 2005; Schmidt, 2005); and DIME deposits specifically have recently been linked to hepatic steatosis, or fatty liver (Heszlein-Lossius et al., 2020; forthcoming). A team of doctors is currently examining the effects of DIME in Gaza but not without difficulty, as one of its senior physicians explained in personal correspondence: “it's almost impossible to do research in Gaza, Israel doesn't allow you to take out any biological material and the facilities aren't there to do analysis in-country because Israel won't allow equipment to be imported". The result is that "a decent scientific protocol is almost impossible, so there's a lot of knowledge that remains in the dark and so we don't yet know what these bombs do".ii

Thinking from the ground, and critically with the knowledge currently available, teaches us that the time-spaces of late modern war are not so much compressed as expansive. An attendant and empirically driven geographical agenda would address the practices of war (e.g., the use of DU, WP and DIME) in commensurate temporal and spatial terms, tracking the deferral and dispersal of harm at the nexus of nonlife and life as they map onto (and collapse) the physical and human distinctions within geography as a discipline.

\section{GEONTOPOWER}

The task of this final section is to integrate into an account of power the contingency between war's residual materials, the Earth's constitutive elements of soil, water and air, and the body's vulnerability to 
environmental harm. The overarching connection, the one that holds this contingency together, is a movement through and between nonlife and life and it is in this movement and distinction that I develop an understanding of the function of power in late modern war: as geontological power.

The roots of this power extend deep into the ontological underpinnings of precision warfare. War in this register is most readily premised and critiqued on conceptual lines drawn within a category of life or the 'biontological enclosure of existence' (Povinelli, 2016: 5) - whereby violence unfolds in a biopolitical field in which targets are produced as alternatively un/grievable (Butler, 2009), maim-able (Puar, 2017), bare and/or expendable (Agamben, 1995; Mbembe, 2019). Such lines must necessarily be preceded by a foundational line drawn between life and nonlife that marks the limits of a continuum or distinction within life (e.g., between bios and $z_{0} e$ ) and thus enables a clearer view of de/valued and therefore target-able life. Integrating life/lives into critique of contemporary war is crucial, particularly for the fact that military technologies can make violence abstract where 'inert' battlespace (Kaplan, 2017: 162) is mediated as 'bloodless' and 'antiseptic' (Herold, 2009: 309). For limited space to rehearse established interventions in this area, suffice to recall that attending to the bio-/thanato-/necro-political logics at the centre of military practices allows us to see more clearly how life is made "bare" and thus threatened and taken with impunity (see e.g., Butler, 2004; Gordon, 2008; Gregory, 2017). The ontological frames of war - the 'orchestrative power[s]' of representation at state and military level 'to ratify what will be called reality' (Butler, 2009: 66) - are in this way taken as critical substance to reveal the making, ranking and unmaking of (certain) human life that is constitutive of the (bio)political force of late modern war. Violence in this sense is played out within the precincts of the biologised (zoe) and/or political body (bios).

What remain out of view in these critical exchanges are the extended temporalities of war's materiality, the residues in fields, deserts and urban settings that are concentrated around bombed-out civilian and (para)military infrastructure. While these legacies of precision warfare will likely reach and diminish life, they can only do so by collapsing a distinction between the inert and animate in the domain of the Earth (geos). For Elizabeth Povinelli (2016), the geos is key to an analysis of power that is not limited to a domain of life - or 'biontology' - but is attendant to nonlife as a radical and original state of Being that always contains within it the promise (or threat) of life (thus: 'geontology'). One is therefore not set in contradistinction from the other - nonlife is not figured simply as the absence of life - but as a mutable distinction that is simultaneously the product of 'geontological power' (or 'geontopower') and its manipulable force. Povinelli shows us in her various elaborations (2014; 2015; 2016; 2017) how power works at this originary level to both divide life from nonlife and to instrumentalise that division. Geontopower operates as 'a set of discourse, affects, and tactics' that function 'to maintain or shape the coming relationship of the distinction between Life and Nonlife' (2016:4) and is thus a 'the power of and over Nonlife beings' that sits at a tension between 'reconsolidating this distinction and witnessing its unravelling' (2016: 173). This is an important tension, and one that allows us to get at the deeper workings of power in the practices of late modern war. 
For its advocates, inertness is an existential condition of precision war that is detectable in a range of discourses. For the militarised state, it is routine to claim that "there hasn't been a single collateral death" caused by aerial targeting operations "because of the exceptional proficiency, precision of the capabilities we've been able to develop". iii Figured this way, neat lines are drawn around an instantaneous and thus temporally and spatially contained violence. This idea is routinely reinforced, for instance where Pentagon medics unequivocally counter the suggestion that high cancer rates in Basra are connected to the use of DU: "the medical answer is $n o$ ". iv For other weapons, WP is classed by US and UK militaries as a conventional munition - emphatically: "not a chemical weapon"v - and DIME's inanimacy is nominative where "Dense Inert Metal Explosive" explicates chemical inactivity. Boeing Global Strike Systems markets its weapons in this class ("Focused Lethality Munitions") as 'surgically' accurate, thanks to its "carbon fiber composite warhead case' that provides 'for precision engagements with ultra-low collateral damage outside the blast zone'.vi Lethality is thus 'focused' in the sense that it occurs within - and only within - the temporal and spatial confines of a munition's explosion and therefore precluded from deferred effects. This is further buttressed by the fact that the Convention of Certain Conventional Weapons - a UN-backed international agreement that restricts incendiary weapons (Protocol III) and those with non-detectable fragments (Protocol I) - makes no mention of a range of the stock munitions (DU, WP, DIME included) associated with advanced militaries activities in Iraq, Afghanistan and Gaza. While it is important not to reduce the issue to the cases of only three munitions, they serve to illustrate a base logic to precision in which the enduring materiality of warfare (weapons residues) is either absent or inert, and thus separate - and even hermetically sealed - from war's enduring threat to non/life.

Integrating the geos into the question of power at this point reveals the conceit of such a life-nonlife separation. In as succinct a schematisation as possible: the subterranean is mined for its nonlife products (uranium, tungsten, alloyed metals) that are processed, packaged and re-introduced into the ground where they leach and seep and become generative of neoplasmic life, or tumours. The geos is thus brought into the violent ends of war in two key ways: first in the provision of lifeless (inert) materials with a capacity to take life (i.e., make inert) in precision's compressed time-spaces; and second in the harbouring of those same lifeless materials with a capacity to gradually deteriorate life, or to be generative of new, undesired life. From the viewpoint of the ground therefore, the violence of war issues from the simultaneous delineation and dissolution of a life-nonlife ontological ordering. In these broad sweeps, we could turn to multiple theoretical frames to conceptualise the contingency of (human) life with more-than-human or non-life forms to yield, for instance, an account of biopolitics 'at a nucleic level' (Pugliese, 2020: 96-103), the scalar positions of interacting objects on an 'animacy hierarchy' (Chen, 2012: 5) or the vibrant carcinogenic matter that further pluralises the body as 'an array of bodies' (Bennett, 2010: 112-113, original emphasis). But retaining questions of the inert (and not more-than-human life) and power (not agency) at the centre of analysis requires something of a rolling back of the founding bio-'ontological lock ins' (Joronen and Häkli, 2017: 568) on which such ideas are formed, and therefore a turning away from self-evident distinctions between life and nonlife. 
To undo such distinctions, Povinelli equips us with three analytical figures: the Desert, or that which is 'denuded of life' but that could, 'with the correct deployment of technological expertise or proper stewardship, be (re)made hospitable to life' (2016: 16); the Animist who 'insists that the difference between Life and Nonlife is not a problem because all forms of existence have within them a vital animating,

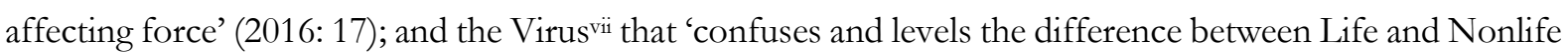
while carefully taking advantage of the minutest aspects of their differentiation' (2016: 19). The temptation - and not an unproductive one - is to arrange these three figures in roman-à-clef form where the Desert, Animist and Virus are each detectable in, respectively, the ground, military and residues. Seen this way, the extractive mining practices that precede munitions production are generative of life in ground elsewhere under the feet of populations in Iraq, Afghanistan and Gaza - a process where the idea of the Desert comes to the fore as a space where life 'is not now, but could be if knowledges, techniques and resources were properly managed' (Povinelli, 2016: 16). Orchestrating this process is the figure of the Animist - 'who can see life where others see the lack of life' (Povinelli, 2016: 18) - at work within the distribution of military violence, mobilising the DNA- and cellular-level quasi- or becoming-life forms that emerge at and effect the collapsing of life into nonlife. These residual forms make for a neat analogy with Povinelli's Virus as the 'active antagonistic agent built out of the collective assemblage that this late liberal geontopower' (2016: 18).

The point however is not simply to map different phenomena onto an existing body of theory but to note the connections with a conceptualisation of power that is hermeneutically and politically kin to the task at hand in the shared objective to understand "from below" - from the ground and the lives it sustains. Geontology derives its power 'from categorising Nonlife as such: as a something that can be said to be lifeless' (Johnson et al., 2019: 1320) then putting it to work at the edges of that categorisation, traversing the boundary it itself produced and instrumentalises. Aside from a set of analogies, then, the account of geontology enables a view of otherwise occluded power dynamics. It becomes significant that governments, military officials, weapons manufacturers and even UN-backed munitions regulators each insist on the inertness of the very weapons associated by doctors in the "global borderlands" with the gradual deterioration of life, or the generation of new, harmful life. In this way, the lauding of "precision" or reduced/zero "collateral damage" is more than a mere (pre-emptive) denial of culpability, it is product and productive of the discursive and affective tactics that draw the lines between life and nonlife on Povinelli's terms. Each Pentagon or MoD official, Boeing executive or weapons inspector who reiterates the accuracy, rapidity and inertness of a munition not only sets temporal and spatial boundaries around violence but also reinforces a line between life and nonlife that denies their contingency, thus occluding a mode of geontopower at function in the ongoing violence of war at ground level.

The question of power in late modern war cannot be answered solely from the viewpoint of aerial assemblages, hyper-technologised battlespace or the notable speeding up of key practices. Instead, as I hope to have illustrated, power functions in significant ways on a geontological level such that we might reformulate what is too often taken as self-evident - that life is threatened by its antithesis, death - to 
recognise that it is in fact Nonlife that must be reckoned with and that as a 'geological concept' (Povinelli, 2016: 175), Nonlife requires us to re-orientate our understandings of power in the context not solely of life but the geos from which bios/thanatos derives and on which it depends.

\section{CONCLUSIONS}

While a majority of research on the theme of late modern war begins at technologies and targeting, my intention here has been to develop a critique of the activities of advanced militaries from the perspective of the ground and the life it sustains. In an important way this builds on key feminist interventions on war and violence 'from below' (Fluri, 2009), and specifically the body-as-battleground (or the battleground-asbody) via 'epistemologically embodied accounts of war' (Hyndman, 2007: 36; see also: Fluri, 2011; Sharp 2020). Crucially, however, I complement a focus on those affected by integrating that affected - and indeed the ontological grounds that enable a distinction between those (life) and that (nonlife). This account of embodiment is thus importantly antecedent in the way it examines the processes that precede the body's emergence as battleground. Viewed this way - specifically from the effects of munitions residue on environments and health in parts of Iraq, Afghanistan and Gaza - we are brought to important understandings of key structuring themes of analysis: the time-spaces of late modern war are not compressed, aerial or remote so much as enduring, terranean and proximate. Entering these time-spaces of war, reveals a particular mode of power that functions through manifold processes - hydrological, agricultural, molecular, cellular, genetic, teratogenic, carcinogenic - and thus, crucially via a designation and dissolution of boundaries between "life" (bios) and "nonlife" (geos). It is in these processes, in the (in)animate, terranean continuities of advanced military practices, that are revealed the geontological time-spaces of late modern war. I will close here with some final words on the significance of the ideas presented in this article for the geographical study of war and the well-adapted capacities for the study of geontologies within geography.

Taken at its broadest, the temporal and spatial re-ordering advocated for here contributes to a project of (re)framing war away from 'official versions' that are, as Judith Butler (2009: xiii) argued cogently, themselves 'part of the materiality of war and the efficacy of its violence' (also: Hyndman, 2007). Taking this thesis seriously means recognising that the idea of war 'is a participatory territorialisation; its definiteness is lent to it by our interest', as Jairus Victor Grove (2019: 70, emphasis added) has recently put it. As participants in this making of analytical time-space, it is on us to lend definitions that do not foreclose war's effects or replicate its logics. This is a criticism I would level at aspects of prominent work on this topic (e.g., Nixon, 2011: 2; also: Pugliese, 2020: 96-103) where the residual effects of weapons unfold 'gradually and out of sight' in war's 'ecological aftermath'. Such an approach accedes to a militaristic temporality in the sense that "after" defers to the formal conclusion of "operations" and betrays a telling positionality: "is violence really slow and "unseen"? What does "slow" mean - slow to whom? Whose gaze is privileged?" (Cahill and Pain, 2019: 1058). The deterioration of health in Fallujah, Mosul, Gaza and so forth occurs very much in sight and - one would guess - quite rapidly from the most important perspective, that of one whose life is degraded by the ground made toxic by war. One suggestion would be to turn to the cognates 
of duress so clearly elaborated by Ann Laura Stoler (2016) as a vocabulary to address the durative temporalities of war and the endurance and duress of affected populations. This could catalyse a much-needed balancing-out in the dynamics of knowledge production on warfare in which our current methods and concepts are rooted in the intentions and practices of militaries rather than the effects for those subjected to war's violent force. A most important potential of the discussion here is to angle scholarly interest in war towards a response to repeated calls from colleagues in Iraq, Afghanistan and Gaza for more resources to effectively research the enduring effects of war and the endurance of populations and infrastructures.

Geographers are uniquely placed to respond to this call. As is illustrated in somewhat dormant but still-relevant debates on the persistence of the unity and division between "physical" and "human" geographies (Harrison et al., 2004; Massey, 1999; O'Sullivan, 2004), there is a breadth of expertise within the discipline that is particularly well-suited to a research problem at the nexus of life and nonlife, or at the designation and dissolution of those categories. Povinelli (2016: 36) formulates this problem as interdisciplinary - 'we need to reopen channels of communication across the natural sciences and critical humanities and social sciences' - but to geographers it might appear intra-disciplinary as we look across department silos (soil science, geology, health, critical and political geography) to pursue research that can piece together evidence of the harms that emerge through the contingencies of life and nonlife. This could take form, for instance, through recently developed notions of 'geopolitical ecology' by adding an examination of war's emissions in the ground to the growing evidence of militaries as major polluters of the atmosphere (see Belcher et al., 2020; Bigger and Neimark, 2019) and/or via longer-established methods of 'following the thing' (Cook, 2004; Gregson et al., 2010) that would push against the secrecy around weapons manufacture that presents a barrier for medical treatments. The methodological stakes are thus high: geographical approaches could identify munition residues and therefore aid clinical management, document their spatial distribution of threat to different communities and determine their provenance in terms of arms production chains, thereby opening lines of political accountability. The imperative must be to strip back the alternatively tacit or explicit assumption that late modern munitions are precise, rapid or inert to pursue an agenda of research that will enable a clearer view of the dynamics and effects of the geontological time-spaces of late modern war.

\footnotetext{
${ }^{\mathrm{i}}$ Importantly, from an OHCHR $(2003,10)$ working paper: 'while there are clear differences of opinion on how bad depleted uranium really is, no one except the military forces using depleted uranium weapons accept that they have no potential to unduly damage both health and environment' (emphasis added).

ii Interview conducted February 2021. Published with permission.

iii John O'Brennan, advisor to President Obama, quoted in New York Times (2011)

iv Dr Michael Kilpatrick, quoted in BBC (2003)

v Pentagon spokesperson, quoted in The Independent (2005)

vi https://www.boeing.ca/products-and-services/defense-space-security/small-diameter-bomb.page

vii Povinelli uses 'the Virus' and 'the Terrorist' somewhat interchangeably, for instance: 'the Virus and its central imaginary of the Terrorist' (2016, 18) and 'THE TERRORIST and its CENTRAL IMAGINARY, the VIRUS' (2017b, 61).
} 


\section{References}

Agamben G (1995) Homo Sacer: Sovereign Power and Bare Life Stanford: Stanford University Press.

Agamben G (2005) State of Exception Chicago: University of Chicago Press.

Agius C (2017) Ordering without bordering: drones, the unbordering of late modern warfare and ontological insecurity. Postcolonial Studies 20(3): 370-386.

Ahmed N (2013) How the World Health Organisation covered up Iraq's nuclear nightmare The Guardian https://www.theguardian.com/environment/earth-insight/2013/oct/13/world-health-organisation-iraq-war-depleted-uranium

Alaani S, Savabieasfahani M, Tafash M and Manduca P (2011) Four polygamous families with congenital birth defects from Fallujah, Iraq. International Journal of Environmental Research and Public Health 8(1): 89-96.

Alaani S, Tafash M, Murie A and Al-Esawi A (2020) High rates of birth defects in Fallujah, Iraq: radiological and chemical pollution of the affected children and their parents. Asian Journal of Immunology 3(1): 1-10.

Alaani S, Al-Fallouji M, Busby C and Hamdan M (2012) Pilot study of congenital anomaly rates at birth in Fallujah, Iraq, 2010. Journal of the Islamic Medical Association of North America 44(1): 1-7.

Al Barqouni L, Skaik S, Nafiz R and Barqouni N (2010) White phosphorus burn. The Lancet 376: 68.

Al-Hamzawi A, Jaafar M and Tawfiq N (2014) Uranium concentration in blood samples of Southern Iraqi leukaemia patients using CR-39 track detector. Journal of Radioanalytical and Nuclear Chemistry 299(3): 1267-1272.

Al Haq (2014) Briefing Note II: The Illegality of Israel's use of DIME weapons https://www.alhaq.org/advocacy/6622.html

Al-Sabbak M, Ali S, Savabi O, Savabi G, Dastgiri S and Savabieasfahani M (2012). Metal contamination and the epidemic of congenital birth defects in Iraqi cities. Bulletin of Environmental Contamination and Toxicology. 89(5): 937-944.

Amnesty (2016) Iraq: Use of white phosphorus munitions puts civilians at grave risk https://www.amnesty.org/en/latest/news/2016/10/iraq-use-of-white-phosphorus-munitions-puts-civilians-at-grave-risk/

Aradau C and Van Munster R (2012) The time/space of preparedness: Anticipating the "next terrorist attack" Space and Culture 15(2): 98-109.

Asaro P (2017) The labour of surveillance and bureaucratized killing: new subjectivities of military drone operators. In Parks L and Kaplan C (eds.) Life in the Age of Drone Warfare Durham: Duke University Press, pp. 282-315.

ATSDR (1997) White Phosphorus - ToxFAQs

https://www.atsdr.cdc.gov/toxfaqs/tfacts103.pdf

Baudrillard J (1995) The GulfWar Did Not Take Place. Bloomington: Indiana University Press.

BBC (2008) Afghan 'health link' to uranium

http://news.bbc.co.uk/1/hi/sci/tech/7373946.stm

Beck R (2003) Remote sensing and GIS as counterterrorism tools in the Afghanistan war: A case study of the Zhawar Kili region. The Professional Geographer 55(2): 170-179.

Belcher O (2011) Introduction: The Occupied Palestinian Territories and Late-modern wars. Human Geography 4(1): 1-9.

Belcher O, Bigger P, Neimark B and Kennelly C (2020) Hidden carbon costs of the "everywhere war": Logistics, geopolitical ecology, and the carbon boot-print of the US military. Transactions of the Institute of British Geographers 45(1): 65-80.

Bell D (2008) Bunker busting and bunker mentalities, or is it safe to be underground? South Atlantic Quarterly 107(2): 213-229.

Benjamin M (2013) Drone Warfare: Killing by Remote Control. London: Verso.

Bennett J (2010) Vibrant Matter: A Political Ecology of Things. Durham: Duke University Press.

Bigger P and Neimark B (2017) Weaponizing nature: The geopolitical ecology of the US Navy's biofuel program. Political Geography 60: 13-22. 
Bishop R (2011) Project 'Transparent Earth' and the autoscopy of aerial targeting: the visual geopolitics of the underground. Theory, Culture \& Society 28(7-8): 270-286.

Bleise A, Danesi P and Burkart W (2003) Properties, use and health effects of depleted uranium (DU): a general overview. Journal of Environmental Radioactivity 64(2-3): 93-112.

Bryant B (2017) Letter form a sensor operator. In Parks L and Kaplan C (eds.) Life in the Age of Drone Warfare Durham: Duke University Press, pp. 315-323.

Butler J (2009) Frames of War. When is Life Grievable? London: Verso.

Butler J (2004) Precarious Life: The Powers of Mourning and Violence London: Verso.

Cahill C and Pain R (2019) Representing slow violence and resistance. ACME: An International Journal for Critical Geographies 18(5): 1054-1065.

Chamayou G (2014) Drone theory London: Penguin.

Chen M (2012) Animacies: Biopolitics, Racial Mattering, and Queer Affect Durham: Duke University Press.

Cook I (2004) Follow the thing: Papaya. Antipode 36(4): 642-664.

DemocracyNow (2009) White Phosphorous and Dense Inert Metal Explosives: Is Israel Using Banned and Experimental Munitions in Gaza?

https://www.democracynow.org/2009/1/14/white_phosphorous_and_dense_inert_metal

Dewachi O (2017) Ungovernable Life: Mandatory Medicine and Statecraft in Iraq. Palo Alto: Stanford University Press.

Duraković A (2005) The quantitative analysis of uranium isotopes in the urine of the civilian population of eastern Afghanistan after Operation Enduring Freedom. Military Medicine 170(4): 277-284.

Dyer C (2009) Doctors call for children injured in Gaza conflict to be monitored for long term effects of new weapons. British Medical Journal 339

Elden S (2013) Secure the volume: Vertical geopolitics and the depth of power. Political Geography 34: 35-51

EPA (2000) Phosphorus: Hazard Summary

https://www.epa.gov/sites/production/files/2016-09/documents/phosphorus.pdf

EPA (2006) Depleted Uranium: Technical Brief

https://www.epa.gov/sites/production/files/2015-05/documents/402-r-06-011.pdf

Fahey D (2003) The Use of Depleted Uranium in the 2003 Iraq War: An Initial Assessment of Information and Policies. https://www.wise-uranium.org/pdf/duiq03.pdf

Fairlie I (2009) Depleted uranium: properties, military use and health risks. Medicine Conflict and Survival 25(1): 41-64.

Fathi R, Matti L, Al-Salih H and Godbold D (2013) Environmental pollution by depleted uranium in Iraq with special reference to Mosul and possible effects on cancer and birth defect rates. Medicine, Conflict and Survival 29(1): 7-25.

Fluri J (2009) Geopolitics of gender and violence 'from below'. Political Geography 28(4): 259-265.

Fluri J (2011) Bodies, bombs and barricades: geographies of conflict and civilian (in) security. Transactions of the Institute of British Geographers 36(2): 280-296.

Foucault M (1978) The History of Sexuality: 1 The Will to Knowledge London: Penguin.

Foucault M (2003) Society Must Be Defended: Lectures at the College de France, 1975-1976 London: Penguin

Foucault (1997) Ethics: Essential Works 1954-84 London: Penguin

Gilbert M and Fosse E (2010) Eyes in Gaza London: Quartet

GlobalSecurity.org (2006) Dense Inert Metal Explosive (DIME)

https://www.globalsecurity.org/military/systems/munitions/dime.htm

Gordon N and Perugini N (2016) The politics of human shielding: On the resignification of space and the constitution of civilians as shields in liberal wars. Environment and Planning D: Society and Space 34(1): 168-187. 
Gordon N and Perugini N (2020) Human Shields: A History of People in the Line of Fire Berkeley: University of California Press.

Gordon N (2008) Israel's Occupation Berkeley: University of California Press.

Graham S (2010) Cities Under Siege: The New Military Urbanism London: Verso.

Gregory D (2004) The Colonial Present: Afghanistan, Palestine, Iraq Oxford: Blackwell.

Gregory D (2006) 'In another time-zone, the bombs fall unsafely...': Targets, Civilians and Late Modern War. The Arab World Geographer 9(2): 88-111.

Gregory D (2010) War and peace. Transactions of the Institute of British Geographers 35(2): 154-186.

Gregory D (2011a) From a view to a kill: Drones and late modern war. Theory, Culture \& Society 28(7-8): 188-215.

Gregory D (2011b) The everywhere war. The Geographical Journal 177(3): 238-250.

Gregory D (2017) Dirty dancing: drones and death in the borderlands. In Parks L and Kaplan C (eds.) Life in the Age of Drone Warfare Durham: Duke University Press, pp. 25-58

Gregson N, Crang M, Ahamed F, Akhter N and Ferdous R (2010) Following things of rubbish value: End-of-life ships, 'chockchocky' furniture and the Bangladeshi middle class consumer. Geoforum 41(6): 846-854.

Grove J (2019) Savage Ecology: War and Geopolitics at the End of the World Durham: Duke University Press.

Hajjar L (2017) Lawfare and armed conflicts. In Parks L and Kaplan C (eds.) Life in the Age of Drone Warfare Durham: Duke University Press, pp. 59-88

Hamada M, Aish A and Shahwan M (2011) Potential of Phosphorus Pollution in The Soil of The Northern Gaza Strip, Palestine. AGRIVTTA, Journal of Agricultural Science 33(3): 291-299.

Harker C (2014) The Only Way Is Up? Ordinary Topologies of Ramallah. International Journal of Urban and Regional Research 38(1): 318-335.

Harrison S, Massey D, Richards K, Magilligan F, Thrift N and Bender B (2004) Thinking across the divide: perspectives on the conversations between physical and human geography. Area 36(4): 435-442.

Herold, M (2009) "Unworthy" Afghan bodies: "smarter" U.S. weapons kill more innocents. In Rockel S and Halpern R (eds.) Inventing Collateral Damage: Civilian Casualties, War, and Empire Toronto: Between the Lines, pp. 303-328.

Heszlein-Lossius H, Ismail A, Al-Borno Y, Shaqqoura S, Skaik N, Al Hinnawi I and Gilbert M (2020) Disturbing medical findings in war-related traumatic amputation patients: a clinical descriptive study from Gaza. British Medical Journal 10(6): 1-6

Hanne Heszlein-Lossius H, Ismail A, Al-Borno, Shaqqoura S, Skaik N, Al Hinnawi I and Gilbert (forthcoming) War related extremity amputations and fatty liver: is there a relation? A clinical follow-up study from Gaza

HRW (2009a) Precisely Wrong: Gaza Civilians Killed by Israeli Drone-Launched Missiles https://www.hrw.org/sites/default/files/reports/iopt0609webwcover_0.pdf

HRW (2009b) Rain of Fire: Israel's Unlawful Use of White Phosphorus in Gaza https://www.hrw.org/report/2009/03/25/rain-fire/israels-unlawful-use-white-phosphorus-gaza

Hyndman J (2007) Feminist geopolitics revisited: Body counts in Iraq. The Professional Geographer 59(1): 35-46.

Jabri V (2006) War, security and the liberal state. Security Dialogue 37(1): 47-64.

Johnson E, Kindervater G, Todd Z, Yusoff K, Woodward K and Povinelli E (2019) Geontographies: On Elizabeth Povinelli's geontologies: A requiem for late liberalism. Environment and Planning C: Politics and Space 37(8): 1319-1342.

Jones C (2016) Lawfare and the juridification of late modern war. Progress in Human Geography 40(2): 221-239.

Jones C (2020) The War Lanyers: The United States, Israel, and Juridical Warfare Oxford: Oxford University Press.

JoPS (2009) The Israeli arsenal deployed against Gaza during operation cast lead Journal of Palestine Studies 38(3): 175-191.

Joronen M (2016) "Death comes knocking on the roof': Thanatopolitics of ethical killing during operation protective edge in Gaza. Antipode 48(2): 336-354. 
Joronen M and Häkli J (2017) Politicizing Ontology. Progress in Human Geography 41(5): 561-579.

Kalinich J, Emond C, Dalton T, Mog S, Coleman G, Kordell J and McClain D (2005) Embedded weapons-grade tungsten alloy shrapnel rapidly induces metastatic high-grade rhabdomyosarcomas in F344 rats. Environmental Health Perspectives 113(6): 729-734.

Kaplan C (2006) Precision targets: GPS and the militarization of US consumer identity. American Quarterly 58(3): 693-713.

Kaplan C (2017) Drone-o-rama: troubling the temporal and spatial logics of distance warfare. In Parks L and Kaplan C (eds.) Life in the Age of Drone Warfare Durham: Duke University Press, pp. 161-177

Kaplan C (2018) Aerial Aftermaths: Wartime from Above. Durham: Duke University Press.

Kaplan R (2006) Hunting the Taliban in Las Vegas The Atlantic Monthly 298(2)

Kinsella H (2011) The Image Before the Weapon: A Critical History of the Distinction Between Combatant and Civilian. Ithaca: Cornell University Press.

Logan D (2018) Toxic violence: The politics of militarized toxicity in Iraq and Afghanistan. Cultural Dynamics 30(4): 253-283.

Loyd J, Ehrkamp P and Secor A (2018) A geopolitics of trauma: Refugee administration and protracted uncertainty in Turkey. Transactions of the Institute of British Geographers 43(3): 377-389.

Manduca P, Barbieri M, Barbieri M, Naeem B, Khalaf H, Ghuris Y, Afifi S, Naeem A and Mughier Y (2009) Gaza Strip, soil has been contaminated due to bombings: population in danger http://newweapons.org/?q=node/110

Manduca P, Diab S, Qouta S, Albarqouni N and Punamaki R (2017) A cross sectional study of the relationship between the exposure of pregnant women to military attacks in 2014 in Gaza and the load of heavy metal contaminants in the hair of mothers and newborns. British Medical Journal 7(7): 1-20.

Massey D (1999) Space-time, 'science'and the relationship between physical geography and human geography. Transactions of the Institute of British Geographers 24(3): 261-276.

Massumi B (2015) Ontopower: War, Powers, and the State of Perception Durham: Duke University Press.

Mbembe A (2019) Necropolitics Durham: Duke University Press.

Mojabi S, Navazi A, Feizi F and Ghourchi M (2010) Environmental Impact of White Phosphorus Weapons on Urban Areas International Conference on Environmental Engineering and Applications 112-116

Müller O (2020) “An Eye Turned into a Weapon”: a Philosophical Investigation of Remote Controlled, Automated, and Autonomous Drone Warfare. Philosophy \& Technology, 1-22.

Naim A, Al Dalies H, El Balawi M, Salem E, Al Meziny K, Al Shawwa R and Manduca P (2012) Birth defects in Gaza: prevalence, types, familiarity and correlation with environmental factors. International Journal of Environmental Research and Public Health 9(5): 17321747.

The Nation (2020) The Children of Fallujah: The Medical Mystery at the Heart of the Iraq War https://www.thenation.com/article/world/fallujah-iraq-birth-defects/

Nixon R (2011) Slow Violence and the Environmentalism of the Poor. Cambridge: Harvard University Press.

O’Sullivan D (2004) Complexity science and human geography. Transactions of the Institute of British Geographers 29(3): 282-295.

Parks L (2017) Vertical Mediation and the US Drone War in the Horn of Africa. In Parks L and Kaplan C (eds.) Life in the Age of Drone Warfare Durham: Duke University Press, pp. 134-157.

Pascucci E (2017) The humanitarian infrastructure and the question of over-research: Reflections on fieldwork in the refugee crises in the Middle East and North Africa. Area 49(2): 249-255.

PENGON (2015) 2014 War on Gaza Strip: Participatory Environmental Impact Assessment https://ps.boell.org/sites/default/files/uploads/2015/12/wareia_report_final.pdf

Povinelli E (2014) Geontologies of the otherwise - Cultural anthropology https://culanth.org/fieldsights/465-geontologies-of-the-otherwise

Povinelli E (2016) Geontologies: A Requiem to Late Liberalism Durham: Duke University Press. 
Povinelli E (2017a) The ends of humans: Anthropocene, autonomism, antagonism, and the illusions of our epoch. South Atlantic Quarterly 116(2): 293-310.

Povinelli E (2017b) The three figures of geontology. In Grusin R (ed.) Anthropocene Feminism Minneapolis: University of Minnesota Press, pp. 49-64.

PHE (2017) White Phosphorus: General Information

https://assets.publishing.service.gov.uk/government/uploads/system/uploads/attachment_data/file/616308/Phosphorus_gene ral_information.pdf

Puar J (2017) The Right to Maim: Debility, Capacity, Disability Durham: Duke University Press.

Pugliese J (2016) Drone casino mimesis: Telewarfare and civil militarization. Journal of Sociology 52(3): 500-521.

Pugliese J (2020) Biopolitics of the More-than-human: Forensic Ecologies of Violence. Durham: Duke University Press.

RAND (2005) A review of the Scientific Literature as it Pertains to Gulf War Illnesses: Volume 7, Depleted Uranium https://www.rand.org/content/dam/rand/pubs/monograph_reports/2005/MR1018.7.pdf

Rockel (2009) Collateral damage: a comparative history. In Rockel S and Halpern R (eds.) Inventing Collateral Damage: Civilian Casualities, War, and Empire. Toronto: Between the Lines, pp. 1-96.

Rockel S and Halpern R (eds.) (2009) Inventing Collateral Damage: Civilian Casualities, War, and Empire. Toronto: Between the Lines.

Royal Society (2002) The Health Hazards of Depleted Uranium Munitions: Part II

https://royalsociety.org/topics-policy/publications/2002/health-uranium-munitions-ii/

Savabieasfahani M, Ahamadani F and Damghani A (2020) Living near an active US military base in Iraq is associated with significantly higher hair thorium and increased likelihood of congenital anomalies in infants and children. Environmental Pollution 256: $1-8$.

Schmidt C (2005) No Magic Bullet: Tungsten Alloy Munitions Pose Unforeseen Threat. Environmental Health Perspectives 113(6).

Shah J (2014) Iraqi Birth Defects Covered Up?

https://www.huffpost.com/entry/iraqi-birth-defects-cover_b_4046442

Sharp J (2020) Materials, forensics and feminist geopolitics. Progress in Human Geography doi.org/10.1177/0309132520905653

Shaw M (2005) The new Western Way of War: Risk-Transfer War and its Crisis in Iraq Cambridge: Polity.

Slesinger I (2020) A cartography of the unknowable: Technology, territory and subterranean agencies in Israel's management of the Gaza tunnels. Geopolitics 25(1): 17-42.

Skaik S, Abu-Shaban N, Abu-Shaban N, Barbieri M, Barbieri M, Giani U and Manduca P (2010) Metals detected by ICP/MS in wound tissue of war injuries without fragments in Gaza. BMC International Health and Human Rights 10(1): 1-14.

Stoler A L (2016) Duress: Imperial Durabilities in our Times Durham: Duke University Press.

UN (2003) Human rights and weapons of mass destruction, or with indiscriminate effect, or of a nature to cause superfluous injury or unnecessary suffering. Working paper submitted by Y.K.J. Yeung Sik Yuen in accordance with Sub-Commission decision 2002/113 https://documents-dds ny.un.org/doc/UNDOC/GEN/G03/144/79/PDF/G0314479.pdf?OpenElement

Webster P (2013) Questions raised over Iraq congenital birth defects study. The Lancet 382(9899): 1165-1166.

Weizman E (2007) Hollow Land: Israel's Architecture of Occupation London: Verso.

Wilcox L (2015) Drone warfare and the making of bodies out of place. Critical Studies on Security 3(1): $127-131$.

Williams A (2011) Enabling persistent presence? Performing the embodied geopolitics of the unmanned aerial vehicle assemblage. Political Geography 30(7): 381-390.

Williams A (2013) Re-orientating vertical geopolitics. Geopolitics 18(1): 225-246.

WHO (2001) Depleted uranium: sources, exposure and health effects

https://apps.who.int/iris/handle/10665/66930

Wolf S, Bebarta V, Bonnett C, Pons P and Cantrill S (2009) Blast injuries. The Lancet 374(9687): 405-415. 
Zehfuss M (2011) Targeting: Precision and the production of ethics. European Journal of International Relations 17(3): 543-566.

Zwijnenburg W (2013) In a state of uncertainty: impact and implications of the use of depleted uranium in Iraq. Report, 7 March. Utrecht: PAX.

https://paxforpeace.nl/media/download/in-a-state-of-uncertainty.pdf

Zwijnenburg W and Weir D (2016) Targets of opportunity: analysis of the use of depleted uranium by A-10s in the 2003 Iraq War. Report, 15 September. Utrecht: PAX and the International Coalition to Ban Depleted Uranium Weapons.

https://paxforpeace.nl/media/download/targets-of-opportunity-pax-icbuw.pdf 